\title{
ANALISIS PENGARUH MOTIVASI TERHADAP KEPUASAN KERJA PEGAWAI PADA RSUD ALIMUDDIN UMAR DI KABUPATEN LAMPUNG BARAT
}

\author{
Siti Amalia ${ }^{(1)}$, Yuliana Yamin ${ }^{(2)}$, Khairul Saleh $^{(3)}$ \\ Fakultas Ekonomi Universitas Sang Bumi Ruwa Jurai \\ amaliasiti_90@gmail.com,yuliana.yamin@fe.saburai.ac.id,khairul.saleh@fe.saburai.ac.id
}

\begin{abstract}
Abstrak. Demi tercapainya tujuan organisasi, pegawai memerlukan motivasi untuk lebih giat dalam bekerja sehingga hasil pekerjaan menjadi lebih baik dan lebih tepat waktu. Melihat pentingnya pegawai dalam organisasi, maka pegawai perlu lebih serius dalam melaksanakan tugasnya sehingga tujuan organisasi dapat tercapai. Dengan motivasi kerja yang tinggi, pegawai akan bekerja lebih giat didalam melaksanakan pekerjaannya. Kondisi yang terjadi pada RSUD Alimuddin Umar di Kabupaten Lampung Barat, utamanya kinerja aparatur pelaksanaannya belum seluruhnya menunjukkan kinerja seperti yang diharapkan pimpinan. Jenis penelitian yang digunakan dalam penelitian ini adalah penelitian lapangan (field reseach), bersifat kuantitatif. Untuk mengetahui tingkat keeratan hubungan antara variabel yang diteliti, maka diperoleh nilai $r$ hitung 0,5114 sedangkan $r$ tabel 32 responden dengan taraf signifikan $5 \%$ adalah $0,297 \%$ berarti $r$ hitung lebih besar dari $r$ tabel. Hal ini menunjukkan adanya pengaruh yang erat antara motivasi dengan kepuasan kerja pegawai. Dari hasil pengolahan data telah berhasil ditemukan jawaban hipotesis yakni sebagai berikut; terdapat pengaruh antara motivasi $(\mathrm{X})$ terhadap kepuasan kerja $(\mathrm{Y})$, dengan tingkat pengaruh (R-square) sebesar $47,6 \%$ yang berarti motivasi memberikan pengaruh sebesar $26,15 \%$ terhadap kepuasan kerja.
\end{abstract}

Kata kunci: Kepuasan, Kerja, Motivasi, Pegawai.

\section{PENDAHULUAN}

Demi tercapainya tujuan organisasi, pegawai memerlukan motivasi untuk lebih giat dalam bekerja sehingga hasil pekerjaan menjadi lebih baik dan lebih tepat waktu. Melihat pentingnya pegawai dalam organisasi, maka pegawai perlu lebih serius dalam melaksanakan tugasnya sehingga tujuan organisasi dapat tercapai. Dengan motivasi kerja yang tinggi, pegawai akan bekerja lebih giat didalam melaksanakan pekerjaannya.

Sebaliknya dengan motivasi kerja yang rendah pegawai tidak mempunyai semangat dalam menyelesaikan pekerjaannya, mudah menyerah, dan memperoleh kesulitan dalam menyelesaikan pekerjaannya, kurang memiliki informasi yang jelas apakah pekerjaan mereka memiliki dampak positif terhadap para penerima manfaatnya yaitu individu atau kelompok yang dilayani organisasi.
Signifikansi tugas seringkali tidak pasti di organisasi - organisasi karena beberapa alasan. Pertama, pegawai di organisasi tersebut sering berpikiran yang buruk, yang membuat ragu apakah tujuan organisasi tersebut sudah tercapai. Kedua, para pegawai seringkali hanya menerima umpan balik langsung yang sedikit tentang bagaimana tindakan - tindakan mereka mempengaruhi penerima manfaat, yang mungkin membuat mereka ragu apakah misi mereka tercapai atau tidak.

Pengembangan sumber daya manusia merupakan unsur dan aset organisasi yang paling penting artinya semakin didasari bahwa manusia tidak boleh diperlakukan sebagai salah satu alat semata tetapi juga harus dianggap sebagai faktor yang amat vital berjalannya sebuah organisasi. Unsurunsur manajemen terdiri dari manusia, alatalat, perlengkapan metode, uang dan pasar, harus diterapkan secara terpadu dan harmonis sedemikian rupa sehingga tujuan 
yang ditetapkan dapat tercapai dengan ketentuan segala sesuatu berlangsung dalam batas waktu, usaha dan biaya yang ditetapkan.

Selain itu, organisasi perlu memperhatikan berbagai faktor yang dapat mempengaruhi motivasi pegawai, dalam hal ini diperlukan adanya peran organisasi dalam meningkatkan motivasi dan menciptakan lingkungan kerja yang kondusif guna mendorong terciptanya sikap dan tindakan yang profesional dalam menyelesaikan pekerjaan sesuai dengan bidang dan tanggung jawab masing-masing.

Demi tercapainya tujuan organisasi, pegawai memerlukan motivasi untuk lebih giat dalam bekerja sehingga hasil pekerjaan menjadi lebih baik dan lebih tepat waktu. Melihat pentingnya pegawai dalam organisasi, maka pegawai perlu lebih serius dalam melaksanakan tugasnya sehingga tujuan organisasi dapat tercapai. Pegawai merupakan aset utama organisasi dan mempunyai peran yang strategis didalam organisasi yaitu sebagai pemikir, perencana, dan pengendali aktivitas organisasi.

Dengan motivasi kerja yang tinggi, pegawai akan bekerja lebih giat didalam melaksanakan pekerjaannya. Sebaliknya dengan motivasi kerja yang rendah pegawai tidak mempunyai semangat dalam menyelesaikan pekerjaannya, mudah menyerah, dan memperoleh kesulitan dalam menyelesaikan pekerjaannya, kurang memiliki informasi yang jelas apakah pekerjaan mereka memiliki dampak positif terhadap para penerima manfaatnya yaitu individu atau kelompok yang dilayani organisasi.

Faktor motivasi dipengaruhi oleh faktor kemampuan dan pengetahuan serta keterampilan. Kemampuan berkaitan erat dengan kecerdasan. Dan kecerdasan seseorang berhubungan dengan latar belakang pendidikan orang tersebut. Sedangkan pengetahuan dan keterampilan yang dimiliki seorang pegawai menunjukkan kadar kompetensi pegawai tersebut yang menunjang tugas dan tanggung jawab terhadap pekerjaannya.

Namun demikian, dalam upaya menciptakan kepuasan kerja, nampaknya masih terdapat kendala yang dihadapi oleh RSUD Alimuddin Umar di Kabupaten Lampung Barat sehingga menghambat tujuan organisasi. Motivasi yang diberikan pimpinan belum mencapai seperti apa yang diharapkan sehingga pegawai tidak mempunyai semangat untuk menyelesaikan pekerjaan. Hal ini terlihat dari adanya pegawai yang mengobrol pada saat jam kerja kantor, lingkungan kerja yang kurang nyaman terlihat dari adanya pedagangpedagang yang masuk ke kantor menawarkan produk sehingga dapat mengganggu aktifitas dalam bekerja.

Kepuasan kerja menurun terlihat dari pegawai yang datang sering terlambat dan istirahat lebih awal. Berbagai kendala tersebut mengakibatkan kepuasan kerja menurun yang disebabkan karena motivasi pegawai yang rendah dalam mengerjakan pekerjaan dan didukung dengan lingkungan kerja yang kurang nyaman sehingga pekerjaan pegawai tidak dapat terselesaikan sesuai dengan yang direncanakan. Kondisi yang terjadi pada RSUD Alimuddin Umar di Kabupaten Lampung Barat, utamanya kinerja aparatur pelaksanaannya belum seluruhnya menunjukkan kinerja seperti yang diharapkan pimpinan.

Dalam kaitannya dengan kepuasan kerja, hal tersebut tentunya harus segera dibenahi agar para pimpinan dan bawahan pada RSUD Alimuddin Umar di Kabupaten Lampung Barat dapat bekerja secara optimal dan bekerja secara lebih profesional. Berdasarkan uraian tersebut maka peneliti akan melakukan penelitian dengan judul: Analisis Pengaruh Motivasi Terhadap Kepuasan Kerja Pegawai Pada RSUD Alimuddin Umar di Kabupaten Lampung Barat. 


\section{KAJIAN TEORI}

\section{Pengertian Motivasi Kerja}

Menurut Winardi (2007), motivasi berasal dari kata motivation yang berarti "menggerakkan". Motivasi merupakan hasil sejumlah proses yang bersifat internal atau eksternal bagi seorang individu, yang menyebabkan timbulnya sikap entutiasme dan persistensi dalam hal melaksanakan kegiatan-kegiatan tertentu. Sedangkan motivasi kerja adalah suatu kekuatan potensial yang ada dalam diri seorang manusia, yang dapat dikembangkannya sendiri atau dikembangkan oleh sejumlah kekuatan luar yang pada intinya berkisar sekitar imbalan moneter dan nonmoneter, yang dapat mempengaruhi hasil kinerjannya secara positif atau secara negatif, hal mana tergantung pada situasi dan kondisi yang dihadapi orang yang bersangkutan.

Menurut A. Anwar Prabu Mangkunegara (2008) memberikan pengertian motivasi dengan kondisi yang berpengaruh membangkitkan, mengarahkan dan memelihara prilaku yang berubungan dengan lingkungan kerja. Menurut $\mathrm{H}$. Hadari Nawawi mendefinisikan motivasi sebagai suatu keadaan yang mendorong atau menjadi sebab seseorang melakukan sesuatu perbuatan atau kegiatan yang berlangsung secara sadar.

Menurut Henry Simamora (2010) pengertian motivasi menurutnya adalah Sebuah fungsi dari pengharapan individu bahwa upaya tertentu akan menghasilkan tingkat kinerja yang pada gilirannya akan membuahkan imbalan atau hasil yang dikehendaki.

Menurut Soemanto (2010) secara umum mendefinisikan motivasi sebagai suatu perubahan tenaga yang ditandai oleh dorongan efektif dan reaksi- reaksi pencapaian tujuan. Karena kelakuan manusia itu selalu bertujuan, kita dapat menyimpulkan bahwa perubahan tenaga yang memberi kekuatan bagi tingkahlaku mencapai tujuan,telah terjadi di dalam diri seseorang.

Dari pengertian-pengertian motivasi diatas maka dapat disimpulkan bahwa motivasi merupakan suatu keadaan atau kondisi yang mendorong, merangsang atau menggerakan seseorang untuk melakukan sesuatu atau kegiatan yang dilakukannya sehingga ia dapat mencapai tujuannya.

\section{Faktor-Faktor Motivasi Kerja}

Sihotang (2007) berpendapat bahwa motivasi kerja melibatkan dua faktor:

1. Faktor-faktor individual
a. Kebutuhan-kebutuhan
b. Tujuan-tujuan orang
c. Sikap-sikap
d. Kemampuan-kemampuan orang

2. Faktor-faktor organisasi

a. Pembayaran gaji/upah

b. Keselamatan kesehatan kerja

c. Para mandor (supervisi)

d. Para pengawas fungsional

Yang merupakan pekerjaan yang sulit dalam memotivasi sumber daya manusia adalah menggabungkan faktor individu dengan faktor organisasi setiap pekerja yang sangat beraneka ragam, karena motivasi seseorang itu dipengaruhi oleh dasar pendidikannya dan kebutuhankebutuhannya.

\section{Pengertian Kepuasan Kerja}

Menurut Locke (Fred Luthan, 2007) definisi komprehensif dari kepuasan kerja yang meliputi reaksi atau sikap kognitif, afektif, dan evaluatif dan menyatakan bahwa kepuasan kerja adalah "keadaan emosi yang senang atau emosi positif yang berasal dari penilaian pekerjaan atau 
pengalaman kerja seseorang." Kepuasan kerja adalah "hasil dari persepsi pegawai mengenai seberapa baik pekerjaan mereka mamberikan hal yang dinilai penting“. Secara umum dalam bidang perilaku organisasi, kepuasan kerja adalah sikap yang paling penting dan sering dipelajari.

Manusia bekerja dalam organisasi tidak dapat melepaskan kepribadian, kepentingannya dan tujuan pribadi yang bersifat organisasional. Untuk itu mereka berusaha agar dapat memenuhi harapan organisasi sehingga tercapai kepuasan kedua belah pihak. Kepuasan kerja pegawai harus diciptakan sebaik-baiknya agar moral kerja , dedikasi, kecintaan dan disiplin pegawai meningkat.

Berdasarkan definisi - definisi diatas dapat ditarik kesimpulan bahwa kepuasan kerja merupakan sikap atau perasaan pekerja terhadap pekerjaannya didasari pada evaluasi terhadap aspek - aspek pekerjaan tersebut, baik menyenangkan ataupun tidak menyenangkan. Tercakup keseluruhan sikap yang yang ditujukan terhadap pekerjaan berdasarkan berbagai evaluasi dari pekerja yang dipertimbangkan seperti aspek gaji, kondisi kerja, supervisi, kualitas kerja dan keamanan kerja. Jadi determinasi kepuasan kerja menurut batasan ini meliputi perbedaan individu maupun lingkungan situasi pekerjaan.

\section{Faktor-Faktor yang Mempengaruhi Kepuasan Kerja}

Banyak faktor-faktor yang mempengaruhi kepuasan kerja pegawai. Peranan faktor-faktor itu sendiri dalam memberikan kepuasan kerja pada pegawai bergantung pada pribadi masing-masing. Faktor-faktor penting yang mempengaruhi kepuasan kerja terdiri dari:

a. Faktor Psikologi, yang merupakan faktor yang berhubungan dengan kejiwaan pegawai, meliputi minat, ketentraman dalam bekerja, bakat dan keterampilan.

b. Faktor sosial, merupakan faktor yang berhubungan dengan interaksi sosial baik antar sesama pegawai atau pegawai dengan atasan.

c. Faktor fisik, merupakan faktor yang berhubungan dengan kondisi fisik pegawai, meliputi jenis pekerjaan, pengaturan waktu kerja dan waktu istirahat, perlengkapan kerja, keadaan ruangan, suhu, penerangan, pertukaran udara, kondisi kesehatan pegawai dan umum.

d. Faktor finansial, merupakan faktor yang berhubungan dengan jaminan serta kesejahteraan pegawai, meliputi sistem dan besarnya gaji, jaminan sosial, macam-macam tunjangan fasilitas yang diberikan serta promosi.

\section{METODE PENELITIAN}

\section{Objek Penelitian}

Dalam penelitian ini yang menjadi objeknya adalah RSUD Alimuddin Umar di Kabupaten Lampung Barat yang beralamat di Jalan Teuku Umar, Kubu Perahu, Balik Bukit, Kabupaten Lampung Barat. Pelaksanaan penelitian mulai bulan April sampai Agustus 2016.

\section{Metode dan Teknik Pengumpulan Data}

Dalam penelitian ini jenis data yang diperlakukan adalah :

1. Data Primer

Data primer merupakan data dasar yang akan diperoleh langsung tanpa perantara orang atau lembaga lain sebagai pihak ketiga. Data primer ini diperoleh dengan wawancara melalui 
responden dengan menggunakan daftar pertanyaan.

\section{Data Sekunder}

Data skunder merupakan data yang diperoleh melalui orang lain yang berhubungan dengan permasalahan yang dipecahkan. Data sekunder ini diperoleh melalui cara studi dokumenter yaitu mengumpulkan dan mempelajari brosur-brosur serta dokumen organisasi.

Penelitian ini dilakukan secara langsung ke RSUD Alimuddin Umar di Kabupaten Lampung Barat, dengan langkah-langkah :

1. Observasi, yaitu pengamatan langsung guna menguji kebenaran hasil wawancara yang telah dilakukan sebelumnya hingga diperoleh bukti dan fakta empiris dari instansi.

2. Wawancara, dilakukan dengan cara bertemu langsung dan bertanya secara langsung dengan pegawai RSUD Alimuddin Umar di Kabupaten Lampung Barat.

3. Kuesioner, yaitu melakukan penyebaran daftar pertanyaan yang diajukan kepada pegawai RSUD Alimuddin Umar di Kabupaten Lampung Barat.

4. Dokumentasi, yaitu merupakan teknik pengumpulan data yang dilakukan dengan cara mencari data mengenai hal-hal yang berhubungan dengan penelitian melalui catatan-catatan atau yang lainnya.

\section{Sampel dan Populasi}

Apabila subjeknya kurang dari 100 lebih baik diambil semua, tetapi apabila subjeknya lebih dari 100 maka dapat diambil 10\%-15\% lebih baik (Arikunto, 2008). Penelitian ini menggunakan sensus, menurut Suharsimi Arikunto, sensus adalah keseluruhan subjek penelitian yang akan diteliti. Responden yang digunakan adalah seluruh pegawai pada RSUD Alimuddin Umar di Kabupaten Lampung Barat yaitu sebanyak 32 Responden.

\section{Metode Analisis Data}

Analisis kualitatif dilakukan dengan cara menggunakan beberapa teori manajemen sumber daya manusia khususnya mengenai pengaruh motivasi kerja terhadap kepuasan kerja pegawai dan melalui data dari pengisian kuesioner pegawai RSUD Alimuddin Umar di Kabupaten Lampung Barat.

Analisis Kuantitatif yang dilakukan berdasarkan data primer yang diperoleh dari penyebaran instrument (daftar pertanyaan) kepada sampel, dan untuk mengetahui pengaruh dari variabel bebas (independen variabel) terhadap variabel terikat (dependen variabel).

Persamaan Regresi Linear Sederhana menentukan persamaan regresi linear sederhana untuk X :

$$
Y=a+b X+e
$$

Keterangan:

$$
\begin{aligned}
& \mathrm{Y}=\text { Kepuasan kerja } \\
& \mathrm{a}=\text { Konstanta } \\
& \mathrm{b}=\text { Koefisien regresi } \mathrm{X} \\
& \mathrm{X}=\text { Motivasi } \\
& \mathrm{e}=\text { Faktor kesalahan }
\end{aligned}
$$

Untuk mengetahui besarnya pengaruh, penghitungan koefisien korelasi tersebut kemudian dilanjutkan dengan Rumus Koefisien Determinasi atau Koefisien Penentu (KP):

$$
K P=(r)^{2} x 100 \%
$$


Untuk menguji secara hipotesis secara parsial digunakan Uji t dengan rumus :

$$
t_{\text {hitung }}=\frac{r \sqrt{N-2}}{\sqrt{1-r^{2}}}
$$

Keterangan:

$$
\begin{array}{ll}
\mathrm{t}_{\text {hitung }} & =\text { Nilai } \mathrm{t} \\
\mathrm{r} & =\text { Koefisien Korelasi } \\
\mathrm{N} & =\text { Jumlah responden }
\end{array}
$$

Kriteria untuk Uji $\mathrm{t}$ adalah sebagai berikut :

a) Jika $t_{\text {hitung }}>t_{\text {tabel }}$ maka Ha diterima dan Ho ditolak.

b) Jika $\mathrm{t}_{\text {hitung }} \leq \mathrm{t}_{\text {tabel }}$ maka Ha ditolak dan Ho diterima.

\section{HASIL DAN PEMBAHASAN}

\section{Analisis Kualitatif}

Untuk mengetahui pengkoordinasian maka dapat dilihat melalui angket yang telah disebar yaitu dengan menggunakan pertanyaan langsung kepada responden dengan menyebarkan angket berjumlah 9 item/pertanyaan, berdasarkan tabulasi data dari variabel motivasi dapat diketahui nilai tertinggi 30 dan nilai terendah 20 sehingga angka-angka tersebut dipakai untuk membuat pengklasifikasian. Dalam hal ini diklasifikasikan ke dalam 3 kategori yaitu tinggi, sedang dan rendah.

Berdasarkan hasil penelitian menunjukkan bahwa responden yang menyatakan Pimpinan menganggap bahwa buah pikiran orang banyak lebih dari seseorang sebanyak 16 responden $(56,82 \%)$ yang menyatakan kadang-kadang sebanyak 10 orang $(34,08 \%)$, dan yang menyatakan tidak sebanyak 6 orang $(9,10 \%)$ Dengan demikian, bahwa koordinasi sudah cukup dan perlu untuk ditingkatkan.

Berdasarkan tabulasi data dari variabel kepuasan kerja dapat diketahui nilai tertinggi 30 dan nilai terendah 17 sehingga angka-angka tersebut dipakai untuk membuat pengklasifikasian. Dalam hal ini diklasifikasikan ke dalam 3 kategori yaitu tinggi, sedang dan rendah. Berdasarkan konsultasi yang dilakukan pada $\mathrm{r}$ tabel tersebut maka ternyata $\mathrm{r}$ hitung $=0,5114$ terletak antara $0,400-0,600$ termasuk sedang.

\section{Analisis Kuantitatif}

Untuk mengetahui apakah hipotesis yang diajukan atau tidak, untuk itu penulis menggunakan uji $t$, dimana diperoleh $r$ sebesar 0,51. Dari perhitungan di atas dapat diperoleh $\mathrm{r}$ hitung sebesar $\mathrm{t}=3,85$ sedangkan $r=$ tabel pada taraf signifikan atau $\alpha 0,05$ sebesar $\mathrm{t}=2,021$ dan $\mathrm{t}$ tabel pada taraf signifikan $1 \%$ atau $\alpha$ sebesar 2,704. Berdasarkan ketentuan tersebut, maka hipotesis nihil (Ho) ditolak karena $\mathrm{t}$ hitung $=3,85$ lebih besar dari $\mathrm{t}$ tabel $=$ 2,021 .

Hal ini berarti bahwa terdapat pengaruh yang positif antara motivasi terhadap kepuasan kerja pegawai. Dari uraian tersebut di atas dapat diketahui bahwa, hipotesis yang dipergunakan dalam penelitian ini adalah motivasi mempunyai pengaruh yang positif dalam usaha meningkatkan kepuasan kerja pegawai pada RSUD Alimuddin Umar Di Kabupaten Lampung Barat dapat diterima.

Koefisien Determinasi $(\mathrm{KD})=\mathrm{R}^{2}=$ $0,690^{2}=0,476=0,476 \times 100 \%=47,60 \%$. Dapat disimpulkan bahwa variabel Motivasi (X) menjelaskan variasi perubahan variabel Kepuasan Kerja (Y) sebesar 47,60\%, sedangkan sisanya dijelaskan oleh faktor lain yang tidak dikaji dalam penelitian ini.

Diketahui persamaan regresi antara motivasi dengan kepuasan kerja yaitu $\mathrm{Y}=$ $11,017+0,704 \mathrm{X}$. Berdasarkan hasil Uji t didapat nilai thitung $=4,885$. Apabila dibandingkan dengan $t_{\text {tabel }}$ pada taraf signifikan yaitu 1,690 , maka thitung $=4,885$ $>\mathrm{t}_{\text {tabel }}=1,690$, sehingga hipotesis yang 
menyatakan terdapat pengaruh antara Variabel Motivasi (X) terhadap Kepuasan Kerja (Y) pada RSUD Alimuddin Umar Di Kabupaten Lampung Barat dapat diterima. Jadi variabel Motivasi berpengaruh terhadap variabel Kepuasan Kerja (Y) pegawai pada RSUD Alimuddin Umar Di Kabupaten Lampung Barat.

\section{KESIMPULAN DAN SARAN}

\section{Kesimpulan}

Berdasarkan penelitian dan pembahasan yang telah dilakukan, maka dapat disimpulkan bahwa motivasi berpengaruh terhadap kepuasan kerja pegawai sebesar 0,476. Hal ini menunjukkan bahwa ada pengaruh motivasi terhadap kepuasan kerja pegawai sebesar $47,60 \%$. Berdasarkan analisis dengan menggunakan Koefisien Determinasi (KD) berarti terdapat pengaruh yang positif dan signifikan antara motivasi dengan kepuasan kerja pegawai pada RSUD Alimuddin Umar Di Kabupaten Lampung Barat.

\section{Saran}

Adapun saran yang diajukan peneliti adalah sebagai berikut :

1. Hendaknya pegawai pada RSUD Alimuddin Umar Di Kabupaten Lampung Barat lebih meningkatkan lagi kinerjanya dengan cara menanamkan rasa memiliki lingkungan kerjanya dan rasa tanggung jawab terhadap tugas yang diberikan kepadanya.

2. Hendaknya pegawai dilingkungan RSUD Alimuddin Umar Di Kabupaten Lampung Barat dibekali pengetahuan dan teknologi yang memadai karena dengan pengetahuan dan teknologi akan sangat membantu dalam penyelesaian masalah kerja.

\section{DAFTAR PUSTAKA}

Arikunto, Suharsimi. 2008. Prosedur Penelitian. Jakarta: Rineka Cipta.

As'ad. 2009. Dasar-Dasar Manajemen. Jakarta: Ghalia Indonesia.

Dessler. 2007. Kepuasan Kerja Pegawai. Jakarta: Erlangga.

Gitosudarmo dan Mulyono. 2007. Manajemen Sumber Daya Manusia. Yogyakarta: Graha Ilmu.

Hasibuan, Malayu S. P. 2009. Manajemen Sumber Daya Manusia. Jakarta: Bumi Aksara.

Handoko. 2008. Dasar, Pengertian dan Masalah Motivasi. Jakarta: Bumi Aksara.

Martoyo. 2010. Motivation in Organization. Alih bahasa oleh Moh Masud, SH.,MA. Jakarta: Erlangga.

Mangkunegara. 2008. Dasar-Dasar Motivasi. Jakarta: Ghalia Indonesia.

Manulang. 2012. Motivasi Kerja Pegawai. Alih bahasa oleh Moh Masud, SH.,MA. Jakarta: Erlangga.

Nanggolan. 2007. Metode Penelitian Sosial; Pendekatan Proposal Penelitian. Bandung: Tarsito.

Nawawi. 2008. Kepemimpinan dan Motivasi. Jakarta: Rineka Cipta.

Robbins, Stephen P. 2005. Perilaku Organisasi Jilid I. Alih bahasa oleh Drs. Hadyana Pujuutmaka dan Drs. Benyamin Molan. Jakarta: Penerbit Prenhallindo.

Soemanto. 2010. Definisi Motivasi. Bandung: Tarsito. 
Siti Amalia : Analisis Pengaruh Motivasi Terhadap Kepuasan Kerja Pegawai Pada Rsud Alimuddin Umar di Kabupaten Lampung Barat

Sihotang. 2007. Metode Riset dan Aplikasinya. Jakarta: Rineka Cipta.

Thoha. 2007. Organisasi dan Manajemen. Jakarta: Ghalia Indonesia.

Umar. 2007. Pedoman Analisis Data Dengan SPSS. Yogyakarta: Graha Ilmu.

Winarti. 2005. Strategi dan Manajemen Sumber Daya Manusia. Jakarta: Bumi Aksara. 